Covered in: CrossRef; RePEC; CEEOL; Google Scholar.

2019, Volume 1, Issue 1, pages: 33-41 | doi: 10.18662/jmsw/03

\section{Improving the Quality of Social Services as a Social Welfare Indicator}

\section{Mariana BRUMĂ (MANCAŞ) ${ }^{1}$}

${ }^{1} \mathrm{MA}$, Faculty of Law and Administrative Sciences, "Ştefan cel Mare" University from Suceava, Romania.
Abstract: The issue of social protection of vulnerable categories of population (children in difficulty, the elderly, people with disabilities, people or families affected by poverty) is a topic of interest, largely in the context of the need to comply with international norms and requirements in the field, and this concern is reflected a constantly improved legal package in the field of social work. Along with the increase number and diversity of social services provided by institutions, control structures have been set up to monitor the quality of the respective services. The question that arises is to what extent the established standards, as an objective grid for measuring the quality of services, also ensure an increase in the quality of life and well-being of direct beneficiaries, as well as their subjective perception. To this end, we made an analysis of the degree of satisfaction of disabled persons institutionalized in a day care center. Our aim is to operationalize the concept of well-being for elderly people with disabilities. The analysis aims to balance the objective and subjective factors of assesing the quality of social services. Experience and studies in the field have shown that the outcome of the intervention is often correlated to the expectations of beneficiaries, their understanding of and compliance with the set objectives, their participation in the intervention and compliance with an established program. This endeavour ultimately justificaties the role of case management in social services as a determining factor for ensuring their quality.

Keywords: Social welfare; quality standards; social services; disability; case management.

How to cite: Brumă (Mancaş), M. (2019). Improving the Quality of Social Services as a Social Welfare Indicator. Journal of Mediation \& Social Welfare, 1(1), 33-41. doi:10.18662/jmsw/03 


\section{Introducere}

Problema protecției sociale a categoriilor vulnerabile de populație (copii în dificultate, vârstnici, persoane cu dizabilități, persoane sau familii afectate de sărăcie) este un subiect de interes, în mare parte în contextul necesității alinierii la normele şi cerințele internaţionale în domeniu. În cadrul sistemului de protecție socială, preocuparea pentru conturarea şi îmbunătățirea unui pachet legislativ consistent vizând protecția socială s-a concretizat prin asumarea şi ratificarea de către autoritățile în domeniu a convențiilor internaționale.

Concomitent cu creşterea numărului şi diversificarea tipului de servicii sociale oferite, s-au înfiinţat instituții şi structuri de acreditare şi verificare ce au rolul de a monitoriza asigurarea calităţii serviciilor oferite. $\mathrm{Ne}$ intrebăm în ce măsură standardele stabilite ca şi grilă obiectivă de măsurare a calităţii unui serviciu asigură o creştere a calităţii vieții şi bunăstării beneficiarilor direcți ai instituțiilor ce oferă servicii de asistență socială, în raport cu percepția subiectivă a persoanelor ce beneficiază de aceste servicii. In acest scop, am realizat o analiză referitoare la gradul de satisfacție a persoanelor cu dizabilități înstituționalizate într-un centru de îngrijire şi asistență.

Demersul nostru are ca scop îmbunătăţirea calităţii serviciilor oferite şi operaționalizarea conceptului de bunăstare pentru asistații vârstnici cu dizabilități. Analiza urmăreşte să coreleze legătură factorii obiectivi cu cei subiectivi (gradul de confort), pentru aprecierea calităţii unui serviciu social.

Practica şi studiile în domeniu au evidențiat că rezultatul interventiei în acțiuni ce vizează direct beneficiarul este corelat frecvent cu aşteptările sale, cu înțelegerea şi asumarea de către acesta a obiectivelor stabilite, cu participarea lui la intervenție şi respectarea unui program convenit. Demersul se constituie, în ultimă instanță, într-o susţinere şi justificare a rolului managementului de caz în serviciile sociale, ca factor principal pentru asigurarea calității acestora.

\section{Calitate şi profesionalism în serviciile sociale}

Legea asistenței sociale nr. 292/2011 stabileşte că scopul legiferării în domeniul asistenței sociale este "dezvoltarea capacităților individuale, de grup sau colective pentru asigurarea nevoilor sociale, creşterea calității vieții şi promovarea principiilor de coeziune şi incluziune socială" (art. 2, Legea nr. 292/2011). Acesta este şi motivul pentru care atât autorităţile, cât şi profesioniştii pledează pentru o centrare a sistemului de protecție socială pe 
acordarea de servicii sociale în defavoarea beneficiilor de asistență socială (prestații financiare), iar pe de altă parte pe centrarea intervenției pe persoană.

Dincolo de aspectele ce țin de ieşirea din situația de dificultate cu care se confruntă persoana, serviciile sociale au o componentă ce urmăreşte direct şi nemijlocit creşterea calității vieții persoanei, aspect care intră, de asemenea, în sfera lor de activitate. Putem spune chiar că serviciile sociale aduc, direct şi indirect, bunăstare în societate, ajutând diverse categorii de persoane în dificultate să trăiască demn şi decent, să aibă acces la resurse, să se poată exprima în mod liber, în definitiv, să aibă o bună calitate a vieții, sprijinind familiile acestora să îşi mențină o viaţă socio-profesională normală şi evitând apariția unor fenomene anomice, disfuncționale la nivel social (Cojocaru, 2005: 79).

Potrivit situației date, punem problema: în ce măsură putem vorbi despre conceptul de bunăstare la nivelul beneficiarilor direcți ai serviciilor sociale şi cum asigurăm, respectiv cuantificăm, elementele sale componente. În condițiile în care intervenția socială a specialistului asupra clientului poate fi întreprinsă prin două strategii - a presiunii şi a legitimităţii (Cojocaru, 2005: 79-80) - în concordanţă cu modelul împuternicirii şi al reprezentării (emplowerment) (Luca \& Gîrleanu-Şoitu, 2012; Miftode, 2002), s-au realizat demersuri în stabilirea unor modele teoretice şi practice pentru a identifica şi asigura acele condiții care să genereze şi să asigure o viaţă de calitate a persoanelor care beneficiază de servicii, aşa încât acestea să îşi îndeplinească rolul de contributor la bunăstarea socială.

Astfel, din perspectivă teoretică, accentrul s-a pus pe intervenția personalizată, centrată pe problemă şi management de caz, iar din perspectivă normativă, pe stabilirea unui set de indicatori de calitate pentru serviiciile sociale în general, dar şi pentru fiecare tip de servcii în particular.

Prestarea oricărui serviciu social trebuie să parcurgă obligatoriu etapele de: evaluare inițială, elaborarea planului de intervenție, evaluare complexă, elaborare a planului individualizat de asistență şi îngrijire, implementare a măsurilor prevăzute în aceste planuri, monitorizare şi evaluare a acordării serviciilor (art. 46, Legea nr. 292/2011). Participarea specialiştilor în toate etapele evaluării, planificării, realizării şi evaluării intervenţiei, alături de beneficiar şi, acolo unde este cazul, de membrii familiei acestuia, precum şi utilizarea unor instrumente de lucru standardizate, creează condiţiile pentru un serviciu adecvat, de calitate şi conform aşteptărilor.

La nivelul sistemului de asistență socială, asigurarea calității serviciilor s-a bazat atât pe legiferarea cadrului general de asigurare a calităţii în 
domeniul serviciilor sociale, a criteriilor specifice şi a unui sistem de acreditare a furnizorilor de servicii sociale, cât şi pe stabilirea şi actualizarea de standarde minime de calitate pentru fiecare tip de serviciu.

Calitatea în domeniul serviciilor sociale, ca preocupare permanentă pentru furnizori, pentru personalul serviciilor sociale, precum şi pentru autorităţile publice, este definită ca "ansamblul de cerințe şi condiții ce sunt îndeplinite de furnizori şi de serviciile sociale acordate de aceştia pentru a răspunde nevoilor şi aşteptărilor beneficiarilor" (art. 2, Legea nr. 197/2012).

Standardul minim de calitate, ce redă un "set de criterii aprobate prin acte normative obligatorii la nivel național a căror aplicare asigură un nivel minim acceptabil de performanță al procesului de furnizare a serviciilor sociale" (art. 6 lit. mm, Legea nr. 292/2011), impune pentru fiecare furnizor de servicii cerințe minime. Stabilirea unor standarde minime de calitate şi a unor standarde de cost a devenit necesară datorită unei creşteri a adresabilităţii către serviciile sociale, a identificării unor cazuri grave de încălcare a drepturilor persoanelor asistate, îndeosebi în sistemul rezidențial, dar şi datorită creşterii unei concurențe reale pe "piața serviciilor sociale", în condițiile în care acestea devin atractive şi accesibile pentru mediul privat.

Pe de o parte, adresabilitatea populației către serviciile sociale a crescut, alternativa unui centru rezidențial fiind o variantă acceptată de tot mai mulți vârstnici în situaţii de dependență/dificultate sau de către familiile acestora, iar pe de altă parte, sistemul a încurajat dezvoltarea de servicii sociale în detrimentul prestațiilor financiare. In aceste condiții, se prefigurează tot mai mult necesitatea profesionalizării sistemului şi chiar înfiinţarea unor servicii sociale de calitate superioară.

Ca urmare, la nivelul sistemului social s-au înfiinţat structuri, instituții şi mecanisme care să asigure standardizarea, monitorizarea şi controlul privind respectarea calităţii serviciilor sociale şi asumarea de către autorităţi a rolului ce le revin în asigurarea unor condiții de viaţă decente pentru toți cetățenii. În plus, legiferarea statutului profesiilor din domeniul social, precum şi a statutului si stadardelor managementului de caz sunt factori ce asigură o creştere a calității intervenției ce îmbunătățeşte relaţia dintre sistemul social şi beneficiarii acestuia şi aduc o contribuție considerabilă în ceea ce priveşte calitatea vieții în instituții şi bunăstarea persoanelor aflate în dificultate.

Pe măsură ce serviciile sociale au fost acceptate de către societate ca o alternativă, în special serviciile rezidențiale şi/sau de recuperare destinate persoanelor vârstnice sau celor cu dizabilități, şi se conturează o piaţă a serviciilor rezidențiale, percepția persoanelor asupra serviciilor şi calității vieții devine din ce în ce mai importantă în raport cu standardele formale. 
În practică, pentru îmbunătățirea calității serviciilor, alături de respectarea factorilor obiectivi, aprobați prin standarde, sunt de luat în calcul factori subiectivi, precum percepția persoanei asistate în raport cu ceea ce i se oferă.

Intrucât intervenția în serviciile sociale este centrată pe subiect/persoană, rezultatele acesteia depind de aşteptările beneficiarului, de stabilirea împreună cu acesta a obiectivelor şi de participarea lui la activităţile propuse. În alegerea alternativei şi în asumarea intervenției de către beneficiar, un rol esențial îl are managementul de caz, bazat pe reducerea vulnerabilităţii persoanei prin consiliere, terapie şi intervenţie (Cojocaru, 2005: 162).

Ca metodă de coordonare şi integrare, în literatura de specialitate de dată recentă managementul de caz a fost dezbătut pe larg (Luca \& GîrleanuŞoitu, 2012: 24-37) şi, recent, au fost elaborate reglementări exprese inclusiv pentru persoanele adulte aflate în dificultate (OMMJS nr. 1218/2019).

Managementul de caz este definit în Legea asistenței sociale ca "metodă de coordonare şi integrare a tuturor activităților destinate grupurilor vulnerabile, de organizare şi gestionare a măsurilor de asistență socială specifice, realizate de către asistenții sociali şi/sau diferiţi specialişti, în acord $\mathrm{cu}$ obiectivele stabilite în planurile de intervenție" (art. 6, Legea nr. 292/2011).

\section{Metodologia microcercetării şi eşantionul}

În cercetarea propusă am vizat o analiză referitoare la gradul de satisfacție a persoanelor cu dizabilități înstituționalizate într-un centru de îngrijire şi asistenţă, urmărind în ce măsură respectarea standardelor de calitate în domeniu se reflectă pozitiv în acoperirea nevoilor şi aşteptărilor beneficiarilor. Ca metode de investigare am utilizat chestionarul şi studiul de caz.

Cercetarea a fost realizată într-un centru de îngrijire şi asistență ce respectă standardele minime de calitate în domeniu, instituție cu o capacitate de 50 locuri, în care asistaţii sunt persoane cu dizabilități, cu vârsta, în marea lor majoritate, peste 60 de ani. Chestionarul a fost aplicat pe un eşantion de minim 50\% dintre beneficiari, în vederea identificării unor cazuri relevante, dintre care două ne-au atras în mod deosebit atenția.

Intrebările din chestionar au fost adaptate la capacitatea de înțelegere a respondenților din care a fost format eşantionul. Chestionarul a fost aplicat tuturor asistaților ce au manifestat capacitatea şi disponibilitatea de a 
răspunde la întrebările propuse, iar ei au constituit eşantionul reprezentativ (De Singly, Blachet, Gotman, \& Kaufman, 1998: 47).

Urmărind stabilirea condițiilor de creştere a calității vieții şi bunăstării beneficiarilor direcți şi percepția acestora asupra serviciilor furnizate, întrebările au vizat: procesul de decizie referitor la admiterea persoanei în centru, gradul de satisfacție în raport cu serviciile de îngrijire, medicale, de recuperare şi integrare socială, confortul şi siguranţa resimţite de individ, relațiile acestuia cu ceilalți beneficiari şi cu personalul, existența unei alte opțiuni şi o evaluare subiectivă a bunăstării personale în cadrul instituției, însoțită de eventuale propuneri de îmbunătăţire a serviciilor.

\section{Rezultatele microcercetării în funcție de metoda folosită}

Din analiza chestionarelor a rezultat că majoritatea beneficiarilor sunt mulțumiţi de calitatea serviciilor şi îngrijirii, de relaţiile cu ceilalţi si activităţile propuse. Dintre cele 28 de persoane chestionate, 12 beneficiari declară că membrii familiei au luat decizia alegerii centrului rezidențial, 7 au decis singuri integrarea în centru, iar pentru 7 a decis o persoană din afara familiei. Este de precizat că unii beneficiari din centru au un traseu instituțional sinuos, fiind asistaţi de la vârste mici şi transferaţi în diverse instituții pe măsură ce au înaintat în vârstă sau au intervenit modificări în starea sau situația lor psiho-socială.

Referitor la întrebarea cât de bine se simt în cadrul centrului, 19 beneficiari acordă nota maximă (pe o scală de la 1 la 5), 8 asistați oferă nota 4 şi 1 acordă nota 2 . De menționat că toți beneficiarii care au precizat că familia a stabilit să fie cazați în acel centru se declară complet mulțumiți, oferind nota maximă, şi că cele mai mari nemulţumiri se înregistrează în categoria celor care declară că au ales singuri această instituție.

Concluzionând, răspunsurile sunt de natură a confirma că un centru care respectă standardele de calitate este apreciat de către beneficiari şi răspunde în mare parte nevoilor acestora. $\mathrm{Cu}$ excepția unui chestionar, în toate celelalte s-au acordat calificative foarte bune, spre maxim, cu privire la toți indicatorii propuşi. Acest fapt ne-a determinat să extindem şi să aprofundăm cercetarea, prin utilizarea unei noi metode de cercetare, şi anume studiul de caz, pentru a urmări care sunt factorii şi condițiile care ar determina o percepție negativă şi cum se poate interveni pentru soluţionarea problemelor identificate.

Ne-am oprit asupra a două dintre cazurile din centru, urmărind să corelăm informaţiile oferite în chestionare cu cele obținute prin alte metode de cercetare în asistența socială: observația, analiza documentelor (dosarele 
personale şi de servicii, anchetele sociale, istoricul social şi instituţional), interviul cu beneficiarii şi personalul implicat în servicii (Neamţu, 2003: 230245).

Un prim caz care ne-a atras atenția este cel care acordă o notă deosebit de mică pentru confortul resimțit în centru, calificative medii în aprecierea calităţii serviciilor, răspunsuri negative la itemii care se referă la siguranţă, igienă şi activităţile propuse, în contextul în care sustine ca a ales singur aceast serviciu şi că este cea mai bună alternativă şi în prezent.

Din interviul ce a avut ca scop identificarea factorilor ce au determinat nemulțumirea față de serviciile oferite, rezultă că răspunsurile sunt în strânsă legătură cu creşterea gradului de dependenţă, pe fondul apariției unei cataracte şi implicit a reducerii capacităţii de a realiza şi participa la activităţi, de nemulțumirea datorată faptului ca liftul de pe scara pe care locuieşte este stricat şi până la repararea acestuia posibilitatea de mişcare a persoanei este limitată la palierul pe care locuieşte, în condiţiie în care persoana prezintă deficit motor, deplasându-se în fotoliul rulant.

In plus, în contextul interviului structurat pe tema răspunsului la chestionar, ne informează că solicită restricționarea vizitei unui membru al familiei şi precizează că o vizită relativ recentă primită din partea acestuia i-a creat motive de îngrijorare privind siguranța personală. Având în vedere că persoana a ales această variantă de rezidență şi că nu întrevede o variantă mai bună, corelat cu faptul că acuză relaţii tensionate cu membrii familiei, se pune în discuție necesitatea reluării unui proces de consiliere şi mediere cu membrii familiei.

La polul opus s-au situat răspunsurile unui beneficiar despre care, din studiul documentelor, aveam informații că, în contextul apariției unor probleme de sănătate suplimentare, i-au fost limitate contactele cu ceilalți, posibilitatea participării la programul de recuperare stabilit anterior şi implicarea în activități de timp liber şi art-terapie (pictură, grafică), starea de sănătate nepermițându-i să părăsească patul.

În cadrul interviului, beneficiarul declară ca starea lui actuală îi creează un mare grad de nemulțumire faţă de viaţă, amplificată de sentimentului pesimismului, corelat nu atât cu suferinţa fizică, pe care o depăşeşte în contextul relgiozităţi deosebite, ci mai degrabă cu percepția inutilităţii şi neputinței. Fiind o persoană activă în decursul vieții care s-a specializat în mai multe profesii, după cu accident cerebral şi imobilizare în fotoliul rulant, deşi a preluat manualitatea pe mâna stangă şi a continuat să picteze şi să modeleze în ipsos (cu ajutor), a resimţit actuala situație ca pe o înfrângere personală. 
Interviul a creat oportunitatea evaluării unor alternative pentru stabilirea unor soluții, prin urmare s-a identificat posibilitatea reluării activității grafice a rezidentului, prin utilizarea unui şevalet de birou care îi permite utilizarea la nivelul patului a instrumentului de lucru şi s-a stabilit, ca prioritate, accesibilizarea spațiului personal, astfel încât acesta să îi ofere o cât mai mare libertate de acțiune.

Ca urmare a aplicării chestionarelor, deşi am intervievat peste $50 \%$ dintre rezidenții centrului, am apreciat că rezultatele nu au fost suficiente pentru a contura obiectivul propus. Ulterior, odată cu aprofundarea cercetării şi aplicarea celor două studii de caz, datele astfel colectate ne-au oferit rezultate de natură să valideze ipoteza de cercetare, şi nume că intervenția de calitate în serviciile sociale este preponderent participativă, iar managementul de caz este un factor principal pentru asigurarea calității serviciilor.

Astfel, în primul caz, rezultatele aparent negative ale chestionarului sau transformat într-o oportunitate de a clarifica anumite aspecte care creează dificultăţi persoanei şi determină acesteia disconfort şi într-un prilej de a discuta aspecte cu care se confruntă şi a găsi, împreună cu aceasta, soluții. În cel de al doilea caz prezentat, rezultatul a fost modificarea, de comun acord şi în colaborare de către membrii echipei asistențiale, a planului individualizat de intervenţie.

\section{Concluzii}

In ce priveşte asigurarea calității în serviciile sociale, se remarcă progrese datorate în mod evident crearii unor standardele de calitate la nivel național şi instituirii unui sistem de autoevaluare, evaluare şi monitorizare, a profesionalizării specializate a angajaților din sistemul de asistență socială şi a încurajării concurenței în domeniu, prin sustinerea inițiativelor private.

Studiul de față demonstrează, o dată în plus, importanța managementului de caz în contextul abordării individualizate şi aprofundate, respectiv recunoaşterea importanței implicării beneficiarilor în toate deciziile ce î privesc.

Considerăm, de asemenea, că este important, în acest context, a sublinia rolul managementului de caz în stabilirea de servicii adecvate şi în activitatea de mediere dintre persoană şi instituțiile cu care intră în contact, între cererea şi oferta de servicii, precum şi în asigurarea transferului firesc de la beneficii sociale la servicii sociale. 


\section{References}

Cojocaru, Ş. (2005). Metode apreciative în asistență socială. Ancheta, supervizarea și managementul de caz. [Appreciative methods in social work. Investigation, supervision and case management]. Iaşi, Romania: Polirom.

De Singly, F., Blachet, A., Gotman, A., \& Kaufman, J. C. (1998). Ancheta şi metodele ei: chestionarul, interviul de producere a datelor, interviul comprehensiv [Survey and its methods: the questionnaire, the interview for data collection, the comprehensive interview]. Iaşi, Romania: Polirom.

Luca, C., \& Gîrleanu-Şoitu, D. (Coords.). (2012). Metodologie de lucru în asistenţa psihosocio-juridică a persoanelor vârstnice [Methodology of working in the psychosocial-legal assistance of the elderly]. Iaşi, Romania: Asociația Alternative Sociale.

Miftode, V. (Coord.). (2002). Populații vulnerabile și fenomene de auto-marginalizare [Vulnerable populations and phenomena of self-marginalization]. Iaşi, Romania: Lumen.

Ministry of Labour and Social Justice. (2019). Order no. 1218/2019 for the approval of specific minimum mandatory quality standards regarding the applications of the case management method for the protection of adults with disabilities. Monitorul Oficial al României, 814, 2019, October 08.

Neamţu, G. (2003). Tratat de asistenţă socială [A treatise on social assistance]. Iaşi, Romania: Polirom.

Romanian Parliament. (2011). Law no. 292/2011 on social work. Monitorul Oficial al României, 905, 2011, December 20.

Romanian Parliament. (2012). Law no. 197/2012 regarding quality assurance in the field of social services. Monitorul Oficial al României, 754, 2012, November 09 . 